\title{
¡CAiatunar, CAiATUnAR! PERVIVEncia \\ DE RITOS DE FERTILIDAD PREHISPÁNICA \\ EN LA CLANDESTINIDAD DEL LOA \\ (NORTE DE CHILE)
}

\author{
Lautaro Núñez y Victoria Castro ${ }^{2}$
}

\section{* InTRoducción}

Resumen

La identificación de un manuscrito del siglo XVII que contiene declaraciones sobre procesos de extirpación de idolatrías en los pueblos de Lasana, Caspana y Ayquina, en el río Loa Medio y Superior (Subárea Circumpuneña, II región, Chile), ha permitido analizar algunos ritos agrarios que se consideran de origen prehispánico. Un examen interdisciplinario arqueológico, etnohistórico y etnográfico ha valorado un conjunto de íconos zoomorfos de trascendencia regional, vinculados con buenos augurios para la fertilidad y reproducción de las cosechas. Independientemente de la yuxtaposición de las doctrinas andinas y cristianas promovidas por la evangelización del siglo XVI, la mayor complejidad y arraigamiento de la ritualidad prehispánica habría sostenido en los Andes Meridionales un recurso ideológico orientado a cohesionar el ethos local afectado por el proyecto colonial.

Palabras claves: Rituales prehispánicos - fertilidad - extirpación de idolatrías - río Loa Superior.

Abstract

A manuscript from the 17th century related to the extirpation of idolatry in the villages of Lasana, Caspana and Ayquina, located in de Upper Loa river (Circumpuna subarea), was found and analyzed. In this text some agrarian rituals of prehispanic origin were identified, and studied from an interdisciplinary perspective that considers archaeological, ethnohistoric and ethnographic approaches. Zoomorphic icons with a regional distribution, symbols of good augury for fertility and a successful harvest, were identified. Independent of the juxtaposition of Andean and Christian doctrines as a result of 16 th century evangelization, the complexity and persistence of prehispanic rituals helped in the cohesion of a local ethos threatened by the colonial project.

Key words: Prehispanic rituals - fertility - extirpation of idolatry Upper Loa river.
En los Andes en general y en particular en la región de Atacama, ${ }^{3}$ el reconocimiento de rituales prehispánicos andinos ha sido una de las preocupaciones prioritarias de los estudios de carácter simbólico y cognitivo, a raíz de las dificultades que existen para documentarlos. Sin embargo, las representaciones iconográficas disponibles suelen ser a veces tan naturalistas y explícitas que permiten identificar personajes sacralizados asociados a prácticas psicotrópicas y chamanísticas, así como a determinados cultos, tales como a la fertilidad o al "sacrificador", que se expresan a través de entidades zoomorfas o de seres humanos en acciones elocuentes (Núñez 1961; Berenguer y Martínez 1986; Llagostera et al. 1988; Gallardo et al. 1999).

Por otra parte, las relaciones analógicas con fuentes etnográficas y con materialidades que sobreviven en la ritualidad actual, han optimizado la aproximación a los significados de ciertos artefactos recuperados de contextos funerarios (Latcham 1938; Ryden 1944; Mostny 1969; Berenguer 1985). Sin embargo, a pesar de estos esfuerzos no ha sido fácil el esclarecimiento de la ritualidad prehispánica, especialmente en el caso de sociedades no descritas por los primeros cronistas coloniales.

En las dos últimas décadas el aporte de la documentación etnohistórica y de la etnografía ha permitido avanzar en esta problemática, logrando una estrecha relación entre la

Recibido: mayo 2011. Aceptado: enero 2012.

\footnotetext{
1 Instituto de Investigaciones Arqueológicas y Museo R. P. Gustavo Le Paige (IIAM), Universidad Católica del Norte. Calle Gustavo Le Paige 380 , San Pedro de Atacama, CHILE. Email: lautaro.nunez@hotmail.com

2 Investigadora Asociada al CIHDE, Universidad de Tarapacá, Arica. Las Perdices 575, La Reina, Santiago, CHILE. Email: vcastrorojas@ hotmail.com

3 El territorio que en la Colonia recibió el nombre de Atacama, corresponde actualmente a la II Región de Antofagasta, en el norte desértico chileno.
} 
información proveniente de los manuscritos coloniales, las fuentes orales y las evidencias arqueológicas del Área Andina en general y del Centro Sur Andino en particular (Arnold et al. 1992; Martínez J. L. 1995; Castro 2004). En el caso de la región de Atacama y específicamente en la cuenca del río Salado, ha alcanzado especial relevancia la descripción proveniente de documentos de extirpación de idolatrías del siglo XVII que detalla la existencia de ciertos "ídolos" o representaciones de divinidades que -aunque hasta el momento no han contado con un correlato arqueológico- pueden ser considerados como objetos de culto de origen prehispánico (Castro 1997). ${ }^{4}$

\section{* Los rituales de fertilidad en los pueblos de Lasana, Caspana y Ayquina}

Recientes estudios realizados en el Archivo General de Indias de Sevilla nos permiten ampliar esta línea de investigación y establecer vínculos cruzados entre la documentación etnohistórica, arqueológica y etnográfica, precisamente en relación a la región del Loa, aportando en aspectos poco conocidos del ethos religioso atacameño. Nos referimos al hallazgo de un documento de 1677 titulado "Informaciones de oficio y parte: Domingo Suero Leiton de Rivera, presbítero, cura y vicario del pueblo de San Francisco de Chiochio, provincia de Atacama la Baja" (AGI, LIMA 263, núm. 9, 12 fs; ver transcripción completa del documento en el anexo de este artículo).

Según la documentación registrada, en 1672 el entonces Bachiller Domingo Suero Leiton de Rivera, Cura y Vicario de Atacama la Baja, fue informado de la ejecución de actos idólatras al interior del río Loa. ${ }^{5}$ Ante eso, habría acorda-

Incluyó lo que hoy es la Provincia de El Loa, la puna aledaña y una extensa franja costera (Castro 1997: 57). El borde nororiental de la Provincia de El Loa, incluye el curso del río Loa Medio y Superior y la cuenca del río Salado que hoy comprende los pueblos de Chiu Chiu, Ayquina, Cupo, Caspana y Toconce. El sector sur de la provincia, corresponde a la cuenca del salar de Atacama, cuyo poblado principal es San Pedro de Atacama.

4 En efecto, los "ídolos" o pequeñas estatuillas descritas en la documentación colonial de Atacama, parecen haber sido mantenidos en la clandestinidad, hasta ser descubiertos por los extirpadores en el siglo XVII (Castro 1997).

5 El corregimiento colonial de Atacama estaba organizado en dos doctrinas o curatos. La cabecera administrativa estaba en Atacama la Alta con capital en el pueblo de San Pedro de Atacama. Ubicada do encontrarse en el pueblo de Chiu Chiu con Don Joseph de la Torre y Salassar, escribano del Rey, después de un largo y penoso viaje desde el vecino altiplano de Lípez. Ambos visitaron los pueblos referidos con el fin de retirar tres ídolos, según quedó testificado por el escribano:

"Testimonio de aver quitado ydolos

En testimonio de verdad Martín Peres de estrada notario de visita yo don Josseph de la torre y salassar escrivano del Rey nuestro Señor certifico doy fee y testimonio de verdad a los que el presente vieren como aviendo ydo a los pueblos de Lassana, Caspana y aiquina jurisdision de la provinçia de atacama La vaja desde este pueblo de san françisco de chio chio de dicha provincia en compañia del Bachiller Domingo Suero Leiton de Rivera cura y vicario de dicho pueblo puerto de Cubija y sus anejos Le vi sacar tres ydolos el vno en el dicho pueblo de Lassana en forma de un platillo quadrado de madera de algarobo con dos figuras de ximios en cuio hueco le echavan comidas las primeras que los yndios de dicho pueblo cogian en sus sementeras a quien of resian adorassion, Y el otro en el pueblo de Caspana a manera de lagarto de la mesma madera con la voca avierta al qual le ofresian piedras de varios colores de pedernales y polvos de colores y davanle adorassion en Vn alto serro que mira al de potossí en el dicho pueblo de la Yquina saco el tersero ydolo de en medio de un caudaloso rrio que estava colocado en Vna peña que estava en la mitad de el, y la bañavan las aguas por entrambos lados a este ydolo segun dixeron los casiques le rendían adorassion y culto llevando el prinsipal Governador en las manos Vna olla nueba y otras veses cargandola en las espaldas y llena de mais y ba la yndia mas ansiana con vn palito sutily delgado tocandole y en llegando que llegavan con esta seremonia al rrio quebravan la olla en la dicha peña y levantando el grito a voses desian Caiatunar, que en su lengua materna dissen lo que en nuestro ydioma Hispanico buena cosecha para conservasion de la extirpasion de dichos ydolos yo el presente escrivano en compañia del dicho cura y vicario fui a los paraxes Referidos por caminos muy agrios..." (AGI, Lima 263, 9, fs. 9v-1or)

A continuación analizaremos y comentaremos cada uno de los casos y situaciones descritas en el documento.

en la cuenca del salar homónimo, incluía los oasis y ayllus circundantes y los anexos más distantes de Toconao, Socaire y Peine. Por su parte, el curato de Atacama la Baja, con cabeza doctrinaria en San Francisco de Chiuchiu, comprendía los pueblos o localidades del curso medio del río Loa (Calama, Chiu Chiu y Lasana) y del curso superior del Loa y río Salado (Ayquina y Caspana), junto con el anexo y puerto de Cobija en la costa del Pacífico (Hidalgo 1984). 


\section{El culto a los simios en Lasana}

De la lectura del manuscrito se desprende que la pieza prohibida del pueblo de Lasana, corresponde a un platillo de madera de algarrobo (materia prima local que demuestra que debió haber sido tallado en la región), con un formato cuadrado, que presenta dos figuras de simios. En principio, se pensó en las clásicas tabletas de inhalación de psicoactivos que suelen mostrar una pareja de tallados (Torres 1984, 1987). Sin embargo, su diseño cuadrangular y el espacio del contenedor establecía una relación más coherente con un tipo de recipiente cuya función era contener las primeras "comidas" o las primeras cosechas.

Tristan Platt (1976) demostró que gran parte de las representaciones en el mundo andino están íntimamente ligadas a patrones de dualidad y cuatripartición y que se asocian esencialmente a la búsqueda de equilibrio entre opuestos complementarios, principios que impregnan todas sus esferas de la realidad. En este contexto, la figura de un cuadrado es sin duda significativa. Puede representar los cuatro puntos cardinales, es decir lo que la vista distingue de la superficie de la tierra, y que podría vincularse al sentido que se otorgue a cada esquina de este esquema, que en su concepción más amplia significa "cualquier cosa cuadrada", al menos como aparece descrita a partir del siglo XVI (sensu Ricardo 1586, citado por Platt 1976: 46).

Siempre respecto a la forma, la etnografía de los kallawaya, llamados "médicos itinerantes de los Andes" (Girault 1987), nos enseña que ellos usan una serie de amuletos de distintas formas para fines de protección y bienestar. Entre estos, varios de los que tienen una forma paralelepípeda, cercana al cuadrado, se asocian a la protección de actividades agrícolas (ver Girault 1987: 571, 578). El acercamiento por la forma es sugerente, aun cuando los amuletos contienen una serie de diseños asociados. En definitiva, el cuadrado es también un depósito que puede contener diferentes elementos que presentan un valor de eficacia simbólica y que, en sí mismo, "significa". No tenemos el nombre de este específico platillo, que sin duda lo tuvo, pero podemos ejemplificar con otra forma que en tiempos coloniales fue descrita por Cristóbal de Albornoz en el siglo XVI:

“...Ase de aduertir que unas figuras como carneros de maderay piedray [que] tienen un hueco como tintero, ques donde se muele esta uilca, se a de procurar buscar y destruir. Llámase al tintero uilcana y la adoran y reverencian" (Albornoz [1580], en Duviols 1967: 22).

Entonces, aunque no es posible definir en detalle cómo era ese platillo al que hemos aludido en líneas precedentes, lo más probable es que su función haya sido similar a la vasija chuwa, tan difundida hasta hoy entre los pueblos andinos, para depositar alimentos y bebidas en el "convido" a sus deidades durante el ceremonial de las "mesas" rituales. Hasta ahora, en el noroeste argentino se acostumbra que la "primera porción de los platos ceremoniales y los frutos más perfectos de la cosecha, se siguen ofrendando aún a los númenes nativos" (Mariscotti 1978: 109; Castro y Varela 1994). La siguiente descripción es todavía más directa en términos analógicos:

"Y cuando quieren arar sus chacras asen ofrendas de cuyes, coca y chicha a sus malquis guarís para que les den buenas chacras [...] y que cuando coxen las primeras papas y choclos les ofresen a los dichos malquis en agradesimiento de las buenas chacras que les an dado y en primisias diciéndoles señores resebid lo primero que coxemos..." (Duviols 2003: 484).

Considerando el potencial maicero de la región del Loa, podemos postular que el recipiente referido portaba estas cosechas tempraneras o una comida elaborada con esta base, trasladada hacia un lugar no determinado y que la pareja de simios que lo identificaba debió tener algún rol vinculante con el ceremonial y sus significados.

El registro arqueológico de simios en ofrendas funerarias preincaicas entre los valles y costa de Arica y Loa, permite asegurar que su reproducción iconográfica proviene de la observación de especímenes vivos. En cuanto a su utilización como ofrenda mortuoria, se ha encontrado un cuerpo completo en un cementerio del valle de Azapa (Muñoz 1983). Por su parte, en el cementerio de Chiu Chiu se excavaron fragmentos de piel provenientes de un escudo de cuero (Ryden 1944) y en el de Pisagua, correspondiente al período Tiwanaku, se identificaron osamentas de simio en una urna funeraria (actualmente en la colección Uhle del Museo Histórico de Santiago; Núñez 1984). La primera evidencia mencionada proviene del cementerio Azapa-76 y está asociada a un párvulo enfardado con camisón negro atado con cordelería vegetal, de cúbito dorsal, junto a cerámica de la fase San Miguel (ca. 1100-1350 


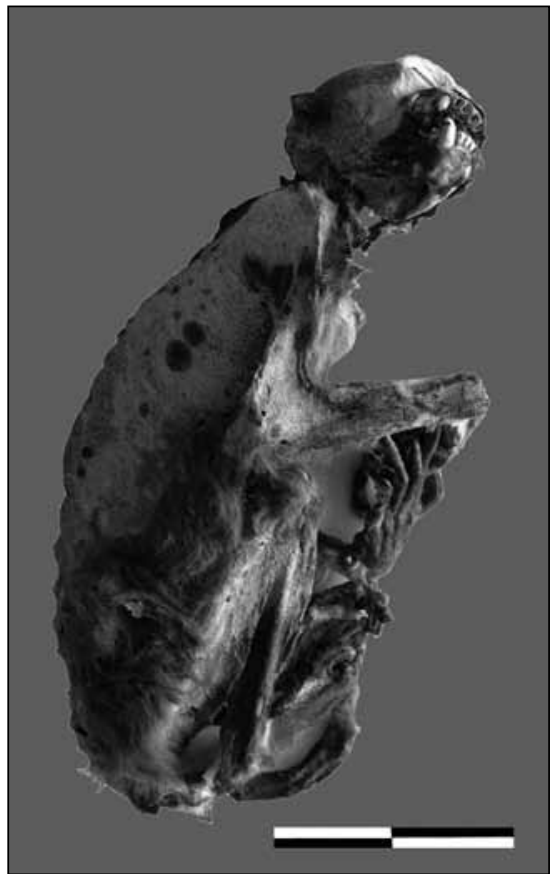

Figura 1. Registro funerario de un simio, correspondiente al Período Intermedio Tardío de la Cultura Arica (Museo de la Universidad de Tarapacá; fotografía gentileza de Iván Muñoz y Wilfredo Faúndez).

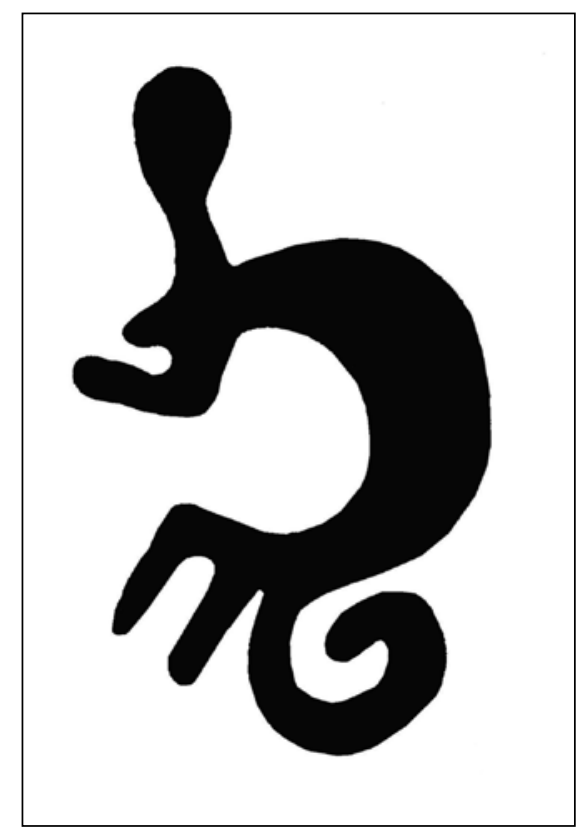

Figura 2. Diseño de un simio en la cerámica gentilar de la Cultura Arica (Muñoz 1983).

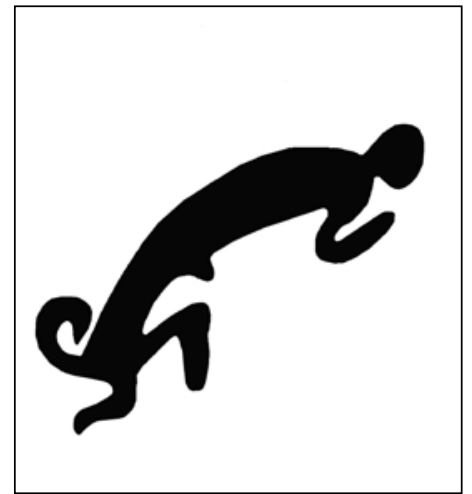

Figura 3. Petroglifo de simio grabado en el sitio preinkaico Tarapacá-47 (Núñez y Briones 1967-68).

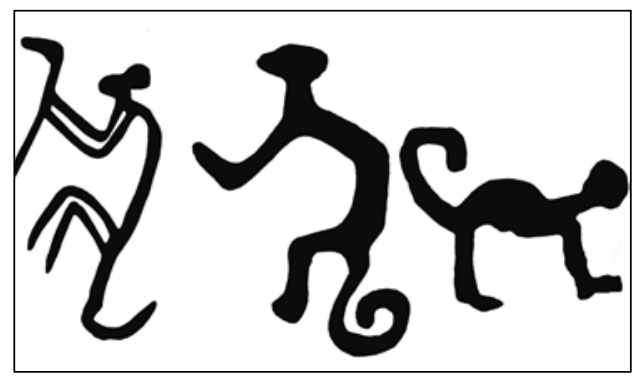

Figura 4. Petroglifos con diseños de simios reproducidos del sitio Río Salado al noroeste de San Pedro de Atacama.

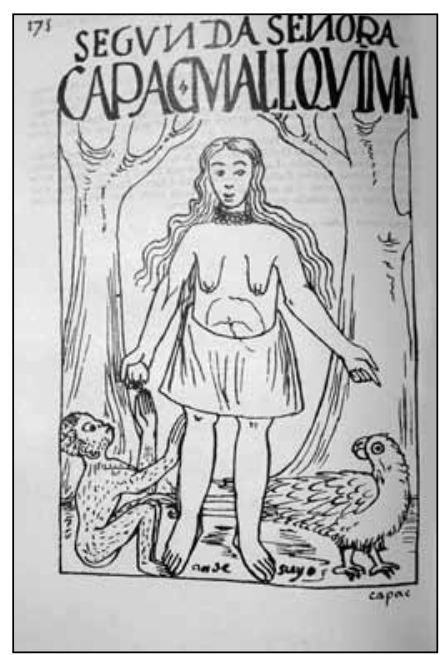

Figura 5. Los íconos de las tierras bajas, correspondientes a simio y guacamayo, incorporados a la parafernalia inka (ilustración de Guaman Poma de Ayala 1936 [1613]). 
DC). En su interior se detectó otra cerámica en forma de kero, una globular con decoración San Miguel, otras dos miniaturas con tapas de fibra vegetal, un cesto ornamentado, dos sandalias y fragmentos de palo cavador y de cuchara de madera. Una vez socavado el espacio de la inhumación, se depositó el fardo y más arriba el mono ofrendado junto a un cesto pequeño, cubierto con una laja horizontal (Muñoz 1983). De acuerdo a un análisis biológico, se determinó su taxa como Alouatta seniculus, correspondiente a un macho aullador rojo, relativamente joven (33-38 meses), trasladado seguramente a tierna edad, puesto que no es fácil mantenerlos en cautiverio fuera de su ambiente selvático (Figura 1). Habría arribado desde las tierras bajas, probablemente desde el área de Santa Cruz (Bolivia) o de Madre de Dios (Perú), aunque esta especie también radica en la región de Corrientes de Argentina (Thorington 1983, en Muñoz 1983).

La presencia de simios en la iconografía del Período Intermedio Tardío de la Cultura Arica es frecuente en diseños de contenedores cerámicos, en asas de keros, en textiles de las fases San Miguel y Gentilar y en el caso de un topo de bronce incaico (Muñoz 1983) (Figura 2). Se presentan en petroglifos ampliamente distribuidos en los Valles Occidentales desde Arica hasta la quebrada de Tarapacá (Figura 3) y también en la circumpuna, con una típica representación de perfil (Núñez y Briones 1967-68) (Figura 4). Su registro en geoglifos abarca desde el valle de Lluta hasta el de Tarapacá (Briones 2008) $y$, en un caso, en la pampa de Nazca cerca de un diseño de picaflor que luego se comentará (Reiche 1982; Moseley 1993). Fuera de dudas, se trata de un ícono intrusivo, aunque reiterado, en las tierras bajas del ámbito más seco del desierto peruano-chileno. Al igual que los guacamayos (Ara militaris), los monos fueron trasladados vivos desde las yungas, constituyendo bienes de privilegio que se introdujeron en el imaginario ritual de las elites y del ceremonial en torno a las wakas y rogativas locales.

Desde la visión etnocéntrica cuzqueña, estos motivos provenían de un espacio marginal y bárbaro, pero es evidente que involucraban poder y estatus: "Tierra caliente y de su naturaleza muy viciosa ay en ella gran suma de ximios y monas de diferentes maneras, papagayos, con otros animales y pájaros muy vistosos como entre otros lo es la guacamaya" (Anello Oliva 1895 [1598]). Cuando Guaman Poma de Ayala (1936 [1614]: 125, 127) repre- senta a la segunda señora Capac Mallquima del Andesuyu selvático solo con cobertura púbica, alude precisamente a gentes diferentes e infieles y "por conquistar", integrando los íconos prestigiosos del simio y guacamayo a cada lado, asimilados en la propia parafernalia cuzqueña (Figura 5). Allí se trataba a los monos o cusillos con mucho afecto, como si fueran sus propios hijos, por su sentido de la imitación, sus gestos, sus conductas sociales y su fragilidad, que en general exigían de mucho cuidado por sus dificultades de adaptación a las tierras altas (Cobo $1956[1653])$.

En los Valles Occidentales se establecieron varias conexiones caravaneras de larga distancia que implicaron contactos con las poblaciones del Andesuyu, adquiriendo bienes de prestigio derivados de la flora y fauna selvática, y que en general apelaban a prácticas rituales, chamanísticas, sanitarias y de sortilegios, asociadas al traslado de alucinógenos, alcaloides, sustancias fumatorias y medicinales, conchas, semillas huayruros (Abrus precatorius L.), jaguares, coatís, caimanes, simios, guacamayos y otros (Montell 1926; Ryden 1944; Núñez 1984; Núñez et al. 2007). Acorde con estos antecedentes, en el valle costeño de Chincha se ha registrado el temprano ingreso de coca, ají, dardos de palma, plumas de pájaros y precisamente el traslado de monos (Rostworowski 1970).

¿Cuál pudo ser el rol de este ícono en la construcción de un imaginario colectivo, sacralizado y tan aceptado en la vertiente occidental andina? En Arica, como en el caso del párvulo señalado más arriba, parece haber representado una ofrenda de elite y como vínculo de afecto en un rico contexto funerario. Debió acompañar al infante en el rito de pasaje, con buenos auspicios y roles protagónicos en el próximo mundo de la vida después de la muerte. Su frecuente representación en diversas artesanías ofrendadas en inhumaciones de distintos rangos etarios, podría sostener esta interpretación como una intermediación ritual.

Hasta el momento, no ha sido posible esclarecer el significado de los simios en el arte rupestre regional. Tampoco hay consenso sobre qué simbolizaron en la pampa de Nazca, donde, entre varias especulaciones, destacamos aquellas que vinculan ciertas líneas monumentales con el manejo de las aguas corrientes, aspecto ritual que adquiere sentido en los ambientes hiperáridos del sur peruano (Moseley 1993) y del norte de Chile (Briones 2008). 


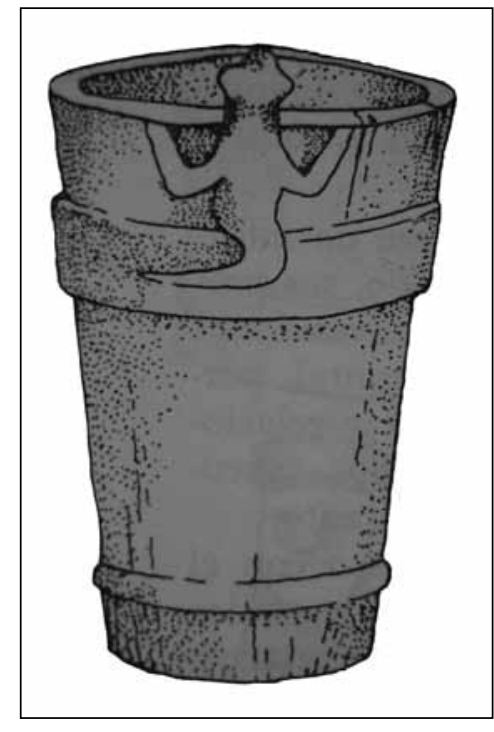

Figura 6. Kero de madera del Período Intermedio Tardío de la Cultura Arica, con diseño del lagarto (Núñez 1963).

Para explorar mejor su significado, es conveniente evaluar desde la lengua aymara el significado del simio (cusillu), que proviene de la idea de cussi, equivalente a "agüero bueno" (Torres 1966 [1616]). Esta percepción se ratifica con cussi como "dicha o ventura o contento" (Anónimo 1970 [1603]). Se podría extender a los deseos de dicha, suerte, fortuna, buenaventura, asociados a la pequeñísima araña llamada Cussi Cussi, que se distribuye hasta el litoral desértico y es reconocida en el altiplano como "un buen agüero de indios" (Anónimo 1970 [1603]). Desde una perspectiva regional, hay estudios de etnozoología que permiten asegurar que la gente de la subregión de río Salado, principal afluente del Loa, distingue varias especies de arañas. En todas ellas se destacan, por ejemplo, los nombre Nina Nina y Cusi Cusi (Castro 1997: 196). Cayon (1971) traduce el nombre de la araña Kusi Kusi como alegría-alegría y señala que etnográficamente en los Andes Centrales es considerada de buena suerte. Como dato ilustrativo es preciso recordar que una araña de $46 \mathrm{~m}$ de longitud, está dibujada en las pampas de Nazca. En ese lugar, la araña y el picaflor tienen las mismas distancias entre los diferentes trechos de sus líneas (ver Reiche 1982: 51). Estos antecedentes tienden a valorar este ícono como señal de un buen presagio, de un anuncio favorable, de que lo esperado o lo hecho saldrá bien, y podría estar vinculado con las rogativas que conducen a un beneficio con buena ventura.
Es posible que estos augurios establezcan una relación directa entre los simios y la fertilidad de la tierra, representada en ese platillo de comida, quizás asociada, además, a los requerimientos de agua en ámbitos desérticos. En efecto, en ciertos mitos de las tierras bajas los monos son "las madres de las lluvias", en tanto que pájaros y monos fueron creados "encima de la tempestad", siempre vinculados con espacios húmedos, con poderes para enjaular al "pájarosol" y con ello anular eventualmente a los días soleados (Levi-Strauss 1986, 1992: 97, 134). Guaman Poma (1936 [1614]) asocia recurrentemente la figura del mono a las coyas esposas de los Inka, lo que puede considerarse como otro augurio vinculado a la buena suerte y la fertilidad.

Esta misma propiedad habría pervivido entre los albañiles andinos cuando levantaban los templos durante la colonia en la actual Bolivia, incorporando este ícono zoomorfo en la base de las columnas (Gisbert y Mesa 1985). En otros casos, se tallaron simios en madera, adosados a ventanales de iglesias, porque se les reconocían valores fabulosos y se los reverenciaba como sustento del buen levantamiento del edificio (Arriaga 1958 [1621]). Estas referencias dan cuenta de la importancia que se les otorgaba, incluso en el siglo XVIII, como una deidad dedicada a apoyar los buenos deseos de perdurabilidad y larga vida, esta vez en la arquitectura que envolvía a la nueva evangelización. A pesar de las campañas de erradicación de las idolatrías, los simios permanecieron en los templos más emblemáticos del altiplano y de las yungas (Gisbert 1980), incluyendo ciertos keros polícromos coloniales (Flores et al. 1998). La doctrina católica no los anatematizó y, por el contrario, los recreó para consolidar su propio dominio, esta vez como símbolos subordinados a los "simios de Dios" (Estenssoro 2001: 455).

\section{El lagarto del ceremonial en un cerro de Caspana}

En este segundo caso descrito en el documento de 1672, el rito se centraba en la cumbre de un cerro alto orientado al de Potosí, utilizando un contenedor de forma no definida, también tallado en madera de algarrobo y con el diseño tridimensional de un lagarto con la boca abierta al que se le ofrendaban pedernales y polvos de varios colores. Desde las investigaciones pioneras, este ícono se ha identificado en las tierras altas de los Andes en algunas estelas preincaicas que presentan motivos de ranas, víboras y lagartijas, como las registradas en Hatuncolla (capital de 


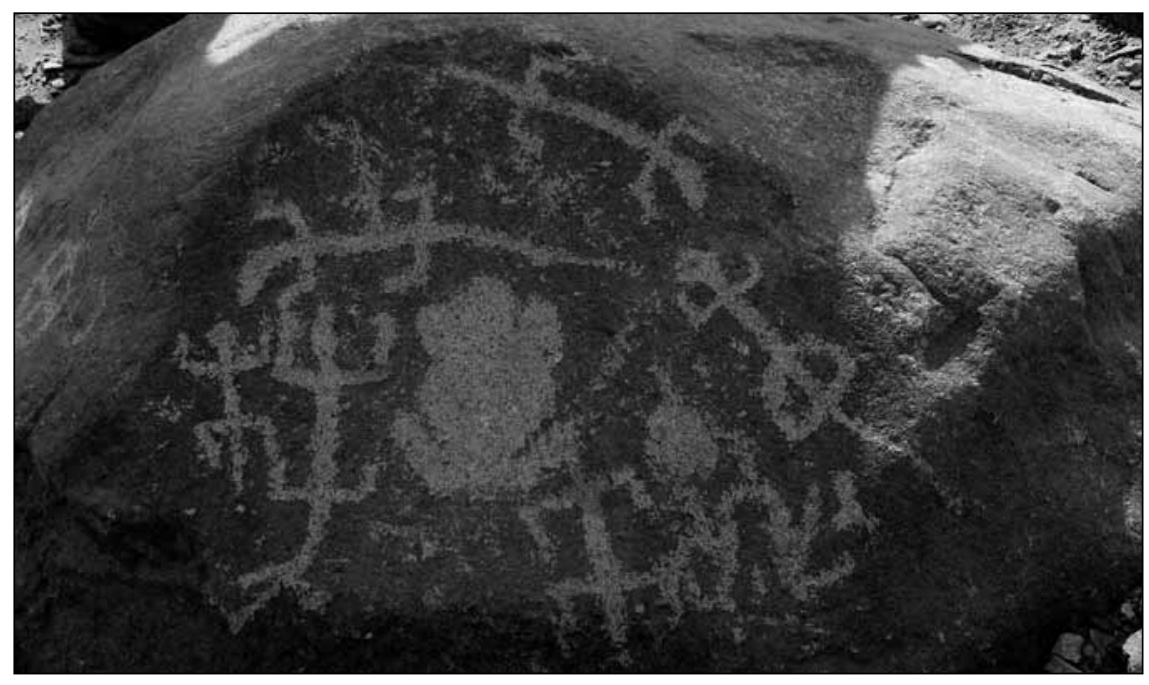

Figura 7. Petroglifo con diseños de lagartijas y sapos del sitio preinkaico Tarapacá-47 (Núñez y Briones 1967-68).

los Collas), lo que demuestra su temprana incorporación en el ceremonial del Altiplano Central (Tschopik 1946).

La figura sauriforme también está presente en la iconografía prehispánica tardía del norte de Chile, pero esta vez sí se corresponde con la fauna local que, hasta la actualidad, se distribuye desde las tierras altas al litoral. Por una parte, se lo encuentra en objetos como los keros de madera, donde aparece tallado al borde de los vasos, y se lo distingue de las representaciones felínicas por su cabeza delicada y cola más alargada, constituyendo el tipo "cuadrúpedo con cola horizontal" (Núñez 1963) (Figura 6). Por otra, este motivo es común en el arte rupestre de los valles y quebradas occidentales como los petroglifos asociados a batracios registrados en cerro Colorado y quebrada de Tarapacá (Briones y Espinoza 1991; Núñez y Briones 1967-1968) (Figura 7). Se lo ha identificado también en diversos geoglifos localizados en ambientes hiperáridos junto a rutas de tráfico caravanero como Soronal, Yungay Bajo, Mapocho, quebrada de Mani, Calera y cerro Colorado, ubicados en la pampa de interfluvio más estéril y carente de recursos de aguas superficiales como el Tamarugal y el este de la cordillera de la Costa. Precisamente, en cerro Colorado se ha observado un diseño monumental que asciende justo por donde escurre el agua de lluvia, durante eventos excepcionales, lo que habría motivado una relación ritual en torno al agua, como reforzando el deseo de recibirla (Briones y Espino- za 1991). En el contexto actual de la sacralización de los mallku o cerros, la etnozoología de las comunidades del río Salado distingue genéricamente a las lagartijas como "cargueros de los mallku". Es decir, como una categoría de animales que tiene el don de poder transportar la riqueza de los cerros masculinos a los cerros femeninos. Adicionalmente, se la describe como vinculada al agua y se denota su virtud medicinal (Castro 1986: 9).

Por otra parte, la recurrencia de diseños de sapos asociados a lagartijas desde períodos preinkaicos de la quebrada de Tarapacá, y su representación en una sola imagen grabada como parte de un mismo discurso visual, permite suponer que esta combinación reforzaría las rogativas en torno al agua. Actualmente, en Bolivia estos batracios y reptiles se valoran como samiris en cuanto atraen la suerte, y hasta son cautivados para ofrecerles ofrendas, libaciones y rogativas con hojas de coca para una mejor fortuna. Como señala Mariscotti (1978: 250), en la localidad de San Pedro, cerca de Oruro "se puede observar dos lagartijas y un sapo de piedra, que son los samiris de Oruro. Cuando estas rocas se mueven, es un presagio de mala suerte".

Si bien el motivo de la lagartija está presente en la iconografía prehispánica, no existen inferencias muy explícitas para entender su significado desde sus propios contextos y representaciones. Sin embargo, los testimonios de las extirpaciones de idolatrías y los cronistas 
reiteran que sapos y lagartijas representan el auspicio del incremento de agua o los buenos augurios para aquellos momentos que se requiere de buena ventura, como los previos a conflictos armados (Cobo 1956 [1653]; Garcilaso 1960 [1609]; Acosta 1954 [1590]). Se ha sugerido que sus ritos, si bien fueron considerados por los incas, tuvieron un rol menor en cuanto provenían de prácticas preexistentes al Estado y al culto solar, vinculados con las ceremonias locales de fertilidad, tal como ocurrió en la Sierra Central del Perú (Mariscotti 1978).

Desde la información etnográfica aymara regional habría consenso en que este ícono estaría relacionado, como los batracios, con las necesidades de lluvias y recursos de agua en general, apuntando directamente hacia la reproducción de la tierra (Van Kessel 1980). En una reciente vilancha ocurrida en el altiplano tarapaqueño (más precisamente desde una cumbre cercana a la estancia de Chulluncane), asistimos a un ceremonial a cargo del Tata Don Eugenio Challapa, dedicado al advenimiento de las lluvias en el que se ofrendó agua del Pacífico junto con agua recuperada del lago Titicaca. En esa ocasión, la presencia de una lagartija, junto a quienes oficiaban el ceremonial, fue considerada como una señal propicia y evidente de que estas rogativas cumplirían su efecto en torno a la fertilidad de la tierra.

En el citado documento de 1672, se señala que al ídolo del pueblo de Caspana, representado "a manera de lagarto", se le ofrecían "piedras de varios colores de pedernales y polvos de colores". ¿Cuál pudo ser el significado ritual de esas rocas y polvos de colores? Del testimonio en cuestión podría deducirse que la presencia de pedernales y polvos se relacionaría con la boca abierta del lagarto. Si esto es así, no es primera vez que se reconoce que ciertas deidades andinas eran alimentadas con minerales semipreciosos macerados y, por cierto, con mullu (Murra 1975: 255-268). Al respecto, el Manuscrito de Huarochirí, refiriéndose a la waka Makawisa, señala que cuando el Inka le ofreció de comer, diciendo "come padre", ésta le respondió: "Yo no tengo la costumbre de comer así. Tráeme Mullu. Cuando le dio el Mullu, Maka Wisa se lo comió de inmediato, haciéndolo sonar 'kap, kap' " (Urioste 1983: 185).

Por otra parte, continuando con el análisis del documento, no se sabe exactamente qué se entiende por pedernales. Lo más probable es que representen a distintas rocas prestigiosas y suficientemente vistosas, utilizadas tanto en el ornato como en prácticas rituales, comunes entre las elites regionales preincaicas, particularmente aquellas localizadas en la circumpuna de la cuenca del Loa y del salar de Atacama: malaquita, turquesa, crisocola y otras (Núñez et al. 2007). En el registro arqueológico son frecuentes las moliendas de estos minerales que eran arrojadas en "pagos" y "challas", al pie de petroglifos, en cajas de ofrendas, en estructuras, en mojones demarcadores de rutas, en "sepulcros" de data prehispánica, en "coveros" y depósitos del templete de Tulán (Núñez et al. 2005).

En conjunto se trata de una materialidad muy involucrada en ceremonias, cuyo prestigio se diseminó incluso fuera del área de Atacama, incorporándose por medio del tráfico de cuentas, a circuitos de intercambio de larga distancia que llegaron a alcanzar el territorio guaraní (Barba 1967 [1639]). El cobre de color, muy propio del desierto circumpuneño, parece haber tenido atributos jerárquicos puesto que sus collares como las conchas del Pacífico fueron usados por las lejanas comunidades del río Pilcomayo y río Grande en la vertiente oriental de los Andes (Martínez Soler 1958-1959).

Desde el inicio del contacto hispánico se identificaron estos minerales y rocas exóticas que, como se ha visto, se vinculaban con diversos rituales aún poco conocidos. Del área del salar de Atacama, proviene la siguiente observación:

"Ay ansy mismo muchas y muy infinitos colores: colorado y azul dacle ultramarino que allá se nombra en Castilla. [...]. Ay verde excelentísimo, parece esmeralda en la color; ay amarillo maravilloso; y blanco y negro muy finos; $y$ de toda suertes de colores" (Bibar 1979 [1558]: 20).

No cabe duda de que los cronistas recogieron desde las elites de Atacama una percepción de riqueza contenida en estos minerales, sustentada en su valoración ideológica que incluía, obviamente, su participación en el aparato religioso. Se describe también como un territorio:

“...donde se crían finíssimas piedras de sangre, leche, esmeraldas, piedras moradas, turquesas, otros géneros de piedras verdes, amarillas, jaspeadas, $y$ de otras suertes muy finas para dar gracias a Dios, que las crió, que cierto es grandíssima riqueza..." (Vásquez de Espinoza 1948 [1628]: 619). 
En los Andes Centrales los ritos dedicados a la fertilidad de la tierra, como el incremento del maíz, se centraban en conopas, es decir en ofrendas de piedrezuelas, figurines de hombres, llamas, maíz y piedras naturales que llamaban la atención por lo peculiar de ciertas manchas y colores. Además, en las casas se ofrecía comida junto a otras ofrendas, como polvo de bermellón (paria), metal verde como cardenillo (llacsa), plumas de guacamayo, pájaros grandes de plumas vistosas, conchas gruesas y rojas de mar (mullu), piedras bezares chicas y plumas de parina (Duviols 2003: 727).

Respecto a los "polvos de colores", mencionados en el documento, se pueden reconocer como colorantes aplicados en distintas pictografías y su procesamiento puede apreciarse en plataformas de molienda y litos con pigmentos, entre otros. Por lo mismo, su identificación en artefactos vinculables, como las "cajitas de colores" tan comunes en la zona del Loa, indica claramente que constituían parte sustancial de la ritualidad prehispánica. Los análisis de muestras arqueológicas han probado el uso de ocres o hidratos y óxidos de hierro, tiza o caolín, óxido de manganeso, carbonatos de cobre, óxido de arsénico y, principalmente, de cinabrio (Latcham 1938). Esto explica que durante el siglo XVI se reconociera en la región circumpuneña la presencia de cardenillo, que es un "compuesto de cobre de color azul o verde que se emplea en la pintura"... y de almagra, correspondiente a "tierra roja que sirve para teñir" (Bibar, 1979 [1558]: 211-213; n. 212 y s.).

Como se describe en el documento de 1672, el ceremonial ocurría en la cumbre de un cerro, previo ascenso seguramente ritualizado, hacia donde "vivían" sus deidades, para instaurar el ceremonial en el ámbito de "arriba" donde radica lo sacro, por sobre el mundo de "abajo" donde se desenvuelve lo profano en el pensamiento andino. El ritual estaba orientado al cerro mayor de Potosí.

Efectivamente, las actuales comunidades aymaras y atacameñas han mantenido, en cuidadosos mapas mentales, el culto a las montañas sagradas de su entorno geográfico, cuyo ceremonial organizaba el calendario litúrgico desde sus círculos regionales de interacción mítica (Castro y Varela 1991). No obstante, sus inserciones en redes espaciales más amplias se conocen poco para vincularlas con seguridad con los apus localizados en los grandes nevados trasandinos. Estos eran venerados con rituales como la qharira, que consistía en aspersiones dedicadas al círculo de los montes más prestigiosos localizados en la línea de altas cumbres de Chile y Bolivia en el norte: Illimani, Mururata, Tres Cruces, Sajama, Huayna Potosí o el Tata Sabaya (Kusch 1970: 91). Si la narrativa ritual de Caspana en el siglo XVII estaba reflejando instituciones prehispánicas, llama la atención que una montaña sagrada tan alejada amparara y tutelara este ceremonial, puesto que hasta ahora no se conoce que los apu de Potosí se relacionen con los menores de la circumpuna.

La montaña sagrada de Potosí fue percibida como un apu principal y poderoso desde antes de los incas, por su fama argentífera y por su propia magnificencia de morfología piramidal, de colorido excepcional, con sus papas de plata boyando hasta en su superficie. Por lo mismo, el culto a la "mullu puerta" (Mullu Punku), ubicada a la entrada de Potosí, convocaba a peregrinos que acudían a esa waka desde más de 300 leguas de distancia (Arriaga 1958 [1559]).

Por cierto que el prestigio de Potosí se acrecentó una vez que la explotación incaica amplió su escala productiva e ideológica, cuando el llamado "Cerro Rico" fue consagrado al sol, constituyendo una waka de trascendencia macrorregional (Cruz y Absi 2008; Bouysse-Cassagne 1997-1998; 2004). Más aún, la ocupación española se apropió de las minas preexistentes y se prospectaron otras vetas, hasta conformar tempranamente el yacimiento más importante del mundo, con una inusual concentración de mano de obra indígena esclavista (mitayos). Fue en el siglo XVI cuando se recogió el mito de que allí, desde tiempos inmemoriales, se había conservado con ofrendas y sacrificios una wanka, que como oráculo indicaba augurios y esclarecía dudas existenciales (Cruz y Absi 2008; Cruz et al. 2005). El foco votivo evolucionó del poder del alma de sus ancestros al supay-demonio de la evangelización.

Aceptamos, en consecuencia, que durante los siglos XIV al XVII y posiblemente hasta el siglo XIX, la montaña de Potosí fue considerada y adorada como un mallku prestigioso desde la vertiente occidental andina, conectado por vínculos mitológicos con estos pueblos periféricos que se enfrentaban ante la paradoja de venerarlo y a su vez saber que allí se desataba una política de exterminio por el trabajo obligatorio impuesto desde la invasión europea. 
Su prestigio como waka inca, consagrada al sol por su riqueza (Bouysse-Cassagne 2004), pudo haber superado a otras cumbres sagradas hasta alcanzar a comunidades tan alejadas como éstas del Loa. No se sabe si sus poderes protegieron, como sucede con otros cerros mallkus regionales, a la productividad de la tierra, las necesidades de agua para sus sementeras o el incremento derivado de sus cosechas. Si esta protección fue cierta, entonces, sus númenes habrían atendido las rogativas desde Caspana y desde sus cumbres, principalmente para la abundancia de las lluvias estivales y para el multiplico de la tierra (Martínez 1976; Mostny et al. 1954; Barthel 1986).

Recientemente, Gisbert (2010), en un acucioso estudio, ha planteado que el adoratorio más importante de la región de Charcas colonial era el mallku o apu de Potosí que estaba dedicado a la deidad de Pachacamac, su dueño. Esta vinculación plantea una profundidad temporal anterior a los incas, quienes aparentemente lo asociaron al sol. Más tarde, los españoles identificaron al cerro con la Virgen María, la que a su vez se identificó con la deidad femenina de la tierra, Pachamama, subsumiendo en este concepto, probablemente, a varias otras deidades.

La población de la vertiente occidental de la puna, particularmente los originarios de la cuenca del río Salado, comparte hasta hoy lazos parentales con gente de Quetena, Alota y Soniquera entre otros pueblos de la vertiente oriental. Después de la Guerra del Pacífico, estos pueblos quedaron separados por las fronteras geopolíticas de Bolivia y Chile, pero no absolutamente incomunicados. Su patrón de asentamiento comprendió en el pasado vastos territorios de ambas vertientes, que les aseguraba contar con lo que podríamos llamar "el granero de Lípez" (vertiente occidental) y mucho más vastas tierras de humedales en la vertiente oriental. Este flujo poblacional estaba cimentado en lazos ideológicos y sociales. Si la sociedad andina en su conjunto comparte estructuras de pensamiento y una cosmovisión, no es para nada extraño que comulguen con la adoración a cerros de carácter pan regional.

\section{Una buena cosecha para Ayquina}

“...en el dicho pueblo de la Yquina saco el tersero ydolo de en medio de un caudaloso rrio que estava colocado en Vna peña que estava en la mitad de el, y la bañavan las aguas por entrambos lados a este ydolo segun dixeron los casiques le rendian adorassion y culto llevando el prinsipal Governador en las manos Vna olla nuebay otras veses cargandola en las espaldas y llena de mais yba la yndia mas ansiana con vn palito sutil y delgado tocandole y en llegando que llegavan con esta seremonia al rrio quebravan la olla en la dicha peña y levantando el grito a voses desian Caiatunar, que en su lengua materna dissen lo que en nuestro ydioma Hispanico buena cosecha..." (AGI, Lima 263, 9, fs. 9v-10r).

En este caso, se han destacado en el documento los siguientes aspectos. Por una parte, un ídolo no descrito, que fue sacado de un peñón rodeado por dos brazos del río tormentoso, donde se ejecutaba un ceremonial a cargo de un "Principal Gobernador". El reconocimiento de "caciques" indicaría que estas autoridades secundarias representarían a varios ayllus y no sería extraño que esta deidad representara a todos los asentamientos que ocupaban el territorio de Ayquina. La máxima autoridad política portaba una olla nueva, quizás de gran factura, colmada de maíces, porque en instantes la cargaba en su espalda. Una anciana la tocaba levemente con un palito, hasta el momento en que sobre el peñón se procedía a quebrarla ante la exclamación icaiatunar! o ibuena cosecha!, según la traducción del kunza transcrita en el mismo manuscrito.

La idea de "Gobernador" (que refiere al cargo que ostentaban las principales autoridades indígenas coloniales) señalaba a un dignatario de rango superior, quizás con vestimenta cumbi, que se acompañaba de las autoridades dependientes, los "caciques", que probablemente conducían a su vez el ceremonial con bienes de estatus, tal como ocurría en diversas regiones de los Andes, como el uso de "collares de esmeraldas", arrojándoles a su paso "polvos de conchas marinas" (Martínez 1995: 59). Siguiendo el patrón andino, debieron ascender hacia los cerros sagrados con las mujeres atrás, portando chicha entre toques de tamborcillos y cantos, hasta alcanzar los "mochaderos" donde ocurría la rogativa. Estos "gobernadores" asumían roles protagónicos en lo político y en lo ritual, principalmente en torno a "la producción y la fertilidad tanto del campo como de aquello que les permitiría su sustento, al tiempo que habría un contenido de protección, que envolvía todo el ámbito de una autoridad" (Martínez 1995: 181).

El ídolo era venerado en el peñón por el "principal" y sus caciques, aunque se puede asumir que el rol de la anciana 
era muy importante, y que desde atrás tañía con un palito "sutil" quizás para lograr algún sonido auspiciatorio. Posiblemente, ambos se unieron simbólicamente para quebrar la olla confeccionada exclusivamente para estos fines. Se había creado, entonces, el mismo escenario que los arqueólogos han registrado frecuentemente cuando en sitios ceremoniales han identificado piezas enteras que fueron fracturadas o "matadas" allí, asociadas a rituales cuyas intenciones son desconocidas.

Este era el momento en que entre una multitud instalada en la ribera del río se había "levantado el grito a voces" en lengua kunza: caiatunar, traducido por los extirpadores de idolatrías como "buena cosecha". Al revisar el vocabulario kunza se puede apreciar el significado de "Ckaya: bien, bueno" y "Ttunar: terreno". Se agrega como ejemplo "Sepetunar: terreno de Peine donde siembran maíz azul" (Vaïsse et al. 1896: 18, 33). Esta es, efectivamente, una exclamación que apela a buenas cosechas de maíz, cuando la olla hecha trizas derrama su contenido sobre el peñón y hacia los dos brazos del río, donde el paso del agua, primero separada y luego confluyendo, también simbolizaba la reproducción deseada.

Especial atención merece la presencia de una anciana que tañía suavemente la olla. Su incorporación podría vincularse en términos de complementariedad de género, escenificando una alegoría a la fecundidad frente a "una capacidad de hacer brotar todo aquello que está en el seno de algo, de hacerlo surgir [...] de allí que relacionemos fecundidad con fertilidad y creación" (Martínez 1995: 190). El protagonismo femenino era sustancial para representar el auspicio y multiplico de todo aquello que se reproduce de la tierra y que en última instancia favorecía el prestigio de las autoridades masculinas desde sus ídolos y wakas que persistían a lo largo del río Loa, incluso ya avanzado el siglo XVII. Pareciera ser muy especulativo aceptar que ella encarnaba a la tierra como fuente de reproducción de alimentos, algo comparable con la deidad Pachamama, tan propia del mundo andino de hoy, precisamente durante los eventos de siembra y cosecha. Al respecto, en el noroeste argentino, en la Quiaca, le corresponde a una anciana representar a la Pachamama en su festividad, sentándose en los costales colmados de granos, asperjados con coca y chicha antes de ser repartidos entre los sembradores. En el caso de los kallahuaya, sucedía al comienzo de la siembra que una mujer de edad avanzada, esta vez cubierta de mantas, se instalaba en el centro de la chacra abrazando, como una madre, un manojo de las primeras cosechas trasladadas desde sembradíos cercanos. Luego, se encendían fogatas para calentar la tierra y hacerla más fértil (Mariscotti 1978).

Es probable que la mujer manejara ciertos ritos de fecundidad en torno a la tierra, con especial énfasis en los tiempos de cosechas, que implicaban un particular polimorfismo derivado de cultos meteorológicos, como ceremonias del "convido" del agua que emana desde las montañas sagradas, entre otras. Estaba muy vinculada místicamente con la reproducción de la tierra, como lo era el parto para el multiplico humano, hasta sintetizarse en la madre tierra, en donde el nacimiento no era distinto a las cosechas, porque compartía la misma autosuficiencia para fecundar, no exenta de ciertos poderes mágicos, propios de su capacidad creativa que la conducía a influir también en la vida del mundo vegetal. Así, durante el ciclo agrario, se ejercitaban cultos con manejos simbólicos donde la fecundidad humana y agraria eran dos creaciones con un mismo significado (Eliade 1998).

El documento descrito jerarquiza el ámbito de un peñón elegido, no al azar, entre dos brazos del río que luego se juntan en un punto de confluencia, el que suele en el Loa, congregar sitios particularmente ceremoniales como los de arte rupestre (Gallardo y Castro 1992: 20). Ese peñón, donde se situaba el ídolo, podría interpretarse como una de las hierofanías que sacralizaban a ciertas rocas hasta materializar allí deidades protectoras, en este caso asociadas posiblemente a los númenes de las aguas fecundantes.

Como se ha planteado, se sacralizaban diversos elementos del medio natural que se destacaran de lo común, que podían ser desde un cerro a una peña, constituyéndolos en referentes rituales como wakas vinculadas a determinados ancestros o fundadores de linajes, incluyendo también augurios de óptimas cosechas. Los nevados, dadores de agua por su altura tan vertical eran los "hanan tayta cerro", esencialmente masculinos y reproductivos, integrados a valles, ríos y lagunas básicamente femeninas (Maldavsky 1999). De modo que todo lo sucedido en el peñón de Ayquina estaría ligado a rogativas orientadas a la reproducción y fertilidad agraria. Hoy en 
día, en un peñón dentro de la cocha de Ayquina (Figura 8), los principales del pueblo hacen sus rogativas para las buenas cosechas en momentos del ritual y ceremonia de la limpia de acequias, invocando al mallku tutelar Paniri (Castro y Varela 1994).

\section{Extirpación y ocultación de las idolatrías. La presencia panandina del picaflor}

Los hechos descritos en el documento analizado, ocurrieron durante el año 1672 , a solo 132 años del primer contacto europeo, cuando aún las campañas de evangelización no eran intensivas ni efectivas, a pesar del rol desempeñado por los templos insertos en los principales asentamientos indígenas del Loa. En efecto, otra misión de extirpación se ejecutó años antes a lo largo del mismo valle hacia 1635, a cargo de Joan Caballero, un alguacil mayor de la cruzada, vecino de Cobija, acompañado del clérigo Francisco Otal (Castro 1997).

No fue fácil erradicar las prácticas religiosas preexistentes a la evangelización, si se acepta que la sociedad local había creado una compleja ritualidad a través de aproximadamente 2000 años de labores agrarias. La pervivencia de ritos prehispánicos en la clandestinidad, que fueron ocultados durante los 37 años que median entre ambas campañas, son una señal de que las expresiones "paganas" eran aún frecuentes a pesar de los castigos recurrentes, desde el siglo XVI, a quienes vivían en la falsedad de sus idolatrías indignas (Halbertal y Margalet 2003).

La extirpación por esos tiempos acudía a penas excesivas con escarnio público, como la incineración de los "ídolos" rescatados del Loa, tal como sucedió en la "plaza" de Calama durante la campaña del clérigo Francisco de Otal (Castro 1997). Se observaron aún acciones más drásticas, ejercidas a comienzos del siglo XVII, cuando un evangelizador indicaba que en la sierra de Arica había quemado "un pueblo que se llamaba Isquiliza, porque los más eran idólatras, muchos avía que no se avían confesado en su vida" (Vásquez de Espinoza 1948 [1628]: 481).

En esta dirección el culto a los íconos zoomorfos era particularmente perseguido por su oposición a la antropomorfización de las imágenes cristianas, haciéndose notar en diversas instancias asociadas a prácticas paganas: vasos, puertas, textilería y otras representaciones prohibidas
(Bouysse-Cassagne 2004). Eran la materialidad misma consagrada a motivar la adoración a través de estos intermediarios sustentados en la "afirmación de que eran capaces de lograr que se produjeran acontecimientos buenos y malos, y que el éxito dependía de que les adoraran" (Halbertal y Margalit 2003: 63). Definitivamente, la coexistencia entre ritos andinos y cristianos durante el siglo XVII configuró una gradiente de menor integración en los asentamientos alejados de los templos principales, con mayor acentuación donde la población europea era mínima, tal como ocurrió en los pueblos de las tierras altas tarapaqueñas y atacameñas (Cereceda 1978; Castro 1997).

Se ha señalado que el prestigio de las deidades zoomorfas provenía de diseños y cultos prehispánicos representados en pictografías, petroglifos, textiles y artesanías, entre otros. Ofidios, aves, batracios y monos tienen una conspicua presencia en el mundo precolombino, aunque solo algunos se han identificado durante el régimen colonial, como los simios y lagartijas, sumados al ícono del picaflor (quenti es su nombre en lengua quechua y sotar en kunza) que fuera venerado también entre los pueblos del Loa y que alcanzó una dimensión regional como Sotar Condi, ${ }^{6}$ el picaflor de la gente (Castro 1997: 184). Se trata de un culto vinculado con el incremento de la reproducción, fecundidad y fructificación de la tierra. Hay indicios plausibles de que esta ave anunciaría tiempos de lluvia e incremento de agua. En efecto, la población de Nazca la incluyó entre sus grandes geoglifos para asegurar la fertilidad de la tierra y la germinación de los cultivos (Reiche 1982; Castro 1997). La trilogía simio-picaflor-araña, destacada en los geoglifos de Nazca, ipodría representar los auspicios de agua para las prácticas agrícolas del desierto más extremo de los Andes?

Se ha planteado que los recursos del desierto peruanochileno, localizado en las tierras bajas, dependen de las fluctuaciones de las lluvias estivales de los ambientes altos o del efecto de la corriente de El Niño. En este marco la observación del cronista Cobo (1956) es acertada cuando señala que el picaflor o colibrí (quenti), después de seis meses colgado, se reanima con el advenimiento de la primavera. Su presencia se corresponde con el comienzo de las siembras, del regadío y de las ceremonias que

\footnotetext{
6 Sotar Condi se traduce como "el picaflor de la gente", de acuerdo al kunza (Castro 1997).
} 


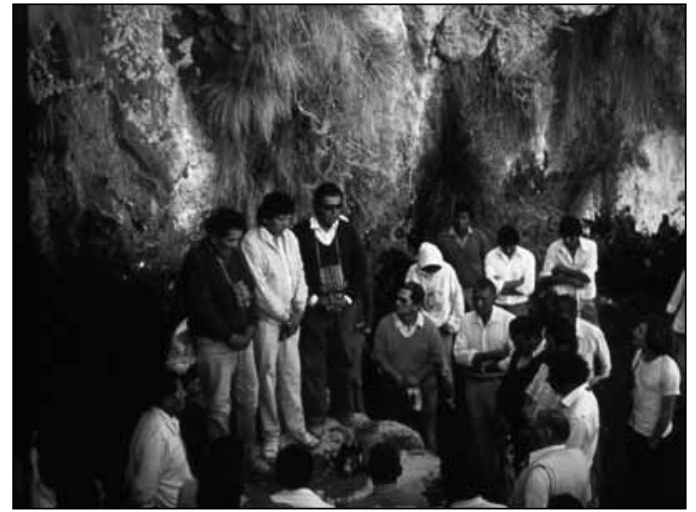

Figura 8. Autoridades y vecinos principales durante las rogativas para mejores cosechas, dispuestos sobre el peñón sacralizado al interior de la cocha de Ayquina (ceremonial de la limpia de acequias; fotografía de Victoria Castro).

dan lugar al inicio del ciclo anual reproductivo "poco más o menos, y en comenzado por la primavera a florecer las plantas torna él a cobrar vida o despertar de aquel largo sueño" (Cobo 1956; Castro 1993, 1997).

El colibrí concentra representaciones de honda significación. Evoca, por ejemplo, la riqueza y colorido de los metales y su capacidad de transformación; su energía y vitalidad denotan la luz, el relámpago, el arcoíris. El quenti o picaflor es reiteradamente asociado por los cronistas al Qollasuyu (Castro 2004: 413), aunque, más omnipresente, parece ser que no solo representa el barrio del sur en el Cusco (quenti), sino también se asociaría a un mito en el orden inicial del mundo (Ponti 2008: 54). En el contexto etnográfico regional lo llaman íntimamente el "pájaro resucitado" o el "pájaro que renace" por su particular etología, que le permite un letargo en la época invernal. Pero, por sobre todo, es polivalente en su significado, confiriéndole la capacidad de producir buena suerte (Castro 2004: 414-415).

La etnografía del picaflor coincide en distintos espacios de los Andes con los inicios de la productividad agraria. Cuando aparece súbitamente en los campos de cultivos, se dice en la región de Puno (Perú), que las plantas florecerán a tiempo. Adicionalmente, se reconoce que "su llegada trae buena cantidad de alimentos de regiones muy lejanas" (Condori 1991: 22). Si el color del plumaje es verde-plateado, se esperan cosechas óptimas, tal como ocurre con las habas. Si combina el azul-verde y plateado, la cosecha de tubérculos será considerable. Por otro lado, si el pico es alongado, habría suficientes alimentos. Por el contrario, vendría un año agrícola pobre, porque podrían ocurrir eventos naturales adversos como las heladas y granizos (Condori 1991).

Se ha propuesto que el culto a Sotar Condi ejerció una irradiación regional, ataviado con vestuario de cumbi "con su pillo y una pluma de oro y otras de pájaro flamenco", lo que mereció su quema ejecutada en Calama (Castro 1997: 134). Esta extirpación sucedida en 1641 se acompañó de otros ídolos, al parecer de valoración más local. Uno de ellos llamado qumaquina o qumaquma, encontrado en la localidad de Chiu Chiu (posiblemente representando una araña); otro llamado Socomba en Ayquina y, por último, Sintalasna o Sintalacna procedente de Caspana. Tanto sus oratorios como los lugares de culto, fueron igualmente incinerados, porque allí se realizaban ritos paganos con sacrificios de llamas, cuyes, chicha, plumas de parina, coca y "yerbas de olor" para sus sahumerios (Castro 1997: 134). En torno a estos tres últimos "ídolos", la documentación consultada no describía sus significados, de modo que no es posible asignarlos al ceremonialismo agrario.

De acuerdo a lo anterior, parece seguro que Sotar Condi representa a ritos de origen prehispánico vinculados con la fertilidad agraria y la reproducción de alimentos. Confirmaría esta propuesta cronológica el registro de un petroglifo con un diseño aislado, correspondiente a un picaflor, identificado como tal, por el ornitólogo cusqueño Dr. José Luis Venero (com. pers. 2009).7 Fue localizado en el tramo donde se encañona la quebrada de los Arrieros en su ascenso a la serranía de Barros Arana, a unos $30 \mathrm{~km}$ al suroeste de San Pedro de Atacama (Núñez et al. 1997). El panel presenta, además, algunos indicadores temporales significativos como el diseño aislado de una ave doméstica europea con percusión fresca, sin pátina, que demostraría su data histórica (es decir colonial o republicana). En ese mismo lugar, el diseño de un picaflor presenta el mismo patinado de los grabados prehispánicos que muestran rostros mascariformes, comunes en la

7 El especialista incluso ofrece algunas especies de colibrí posibles de estar allí representadas. Se podría tratar de una hembra, observada en el cortejo al macho de Amazilia chionogaster, Myrtis Fanny, Rhodospis vesper o Thaumastura cora (com. pers. 27 de mayo 2009). 


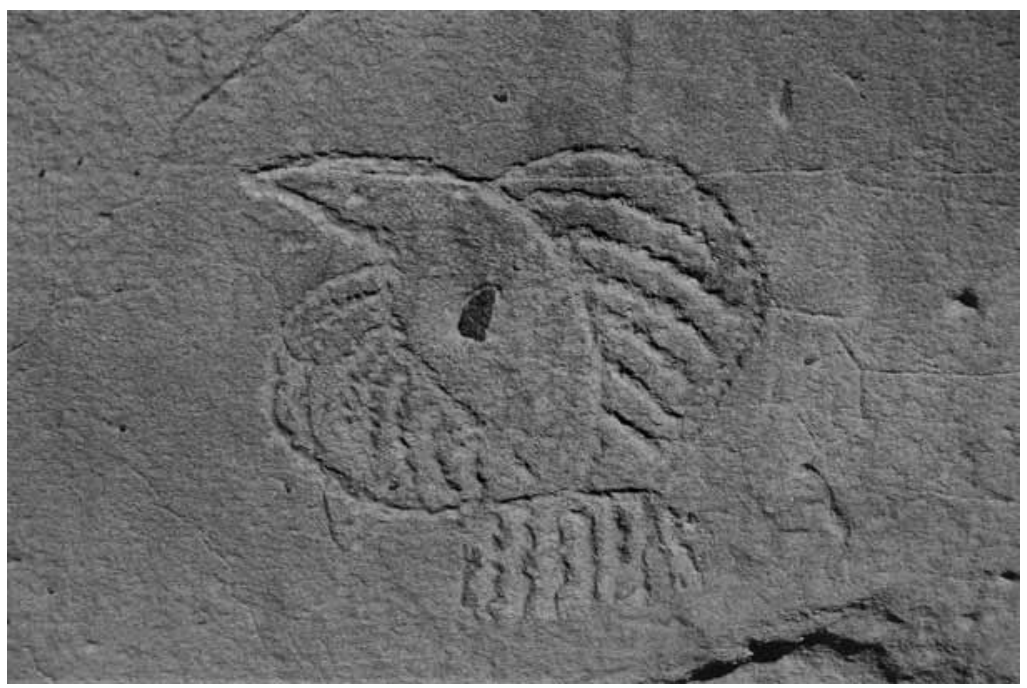

Figura 9. Petroglifo del ícono picaflor grabado en la Quebrada de los Arrieros al suroeste de San Pedro de Atacama (fotografía de Lautaro Núñez).

quebrada de los Tambores (Núñez et al. 1997), situada 30 $\mathrm{km}$ al noroeste de San Pedro de Atacama. Este ícono de alta frecuencia está asociado a la ruta prehispánica tanto de Tambores como de los Arrieros, e indica con seguridad que estamos en presencia de un pasaje de tráfico de interacción entre el valle de Atacama y los focos mineros y agrarios al oeste de la cuenca (Figura 9). Es decir, el registro grabado de un Sotar Condi en la Quebrada de los Arrieros se vincula con una ruta prehispánica. Ésta fue reutilizada durante el proceso colonial y el tráfico de arriería de vacunos desde Argentina a las salitreras, testimoniado por grabados asociados a nombres vinculados con el traslado de remesas ganaderas. En este escenario despoblado, donde la intervención humana está sustentada solo con el flujo caravanero y de arriería, ¿qué rol cumplió el grabado de un picaflor? Se ha probado que, en rutas como éstas, la presencia de petroglifos guarda relación con rogativas orientadas al auspicio y protección durante las travesías de larga distancia. En este sentido, si Sotar Condi anunciaba los buenos augurios para la fertilidad, ¿no podría propiciar la buena ventura del caravaneo orientado hacia el desierto absoluto?

\section{El poderoso soporte piedra}

Desde otras fuentes arqueológicas no ha sido frecuente situar evidencias relacionadas con rituales agrarios de ori- gen prehispánico. Una excepción podrían ser ciertos bloques líticos alargados, con un "acinturamiento" central, denominados "Santos de los Antiguos" (Mostny 1969). Suelen encontrarse durante la remoción o preparación de los campos de cultivo, principalmente entre los asentamientos del río Loa, oportunidad en que se les trata como un objeto de culto "antiguo", eventualmente prehispánico, asociado directamente a los espacios agrícolas.

Las tempranas extirpaciones de idolatrías han identificado ciertamente ídolos líticos, de formatos alargados, a los cuales se les veneraba como wankas protectoras de la producción agrícola. Es muy posible que respondieran a ciertos ritos vinculados con la reproducción de la tierra. Al respecto se han registrado las llamadas "piedras chacanas" que también presentan un típico elongamiento, embutidas en las sementeras y que son reconocidas como un medio para proteger y multiplicar las cosechas (Maldavsky 1999). Parece correcto plantear que la correlación entre los "Santos de los Antiguos" y los espacios cultivados se comprende en relación al incremento de la fertilidad agraria.

Desde la perspectiva de la sociedad andina en general, las rocas elongadas enterradas en sementeras y reconocidas como wankas se vinculan efectivamente con la producción agraria y constituyen una amplia distribución en los Andes, introduciéndose incluso en los propios templos: 
"en la puerta de la sacristía tienen otras dos piedras guancas las quales adoraban y mochaban y de la misma manera las tienen puestas en todas las chacras y este testigo en las suyas porque disen representar a los ydolos guaris que criaron las dichas chacras y las adoran y mochan [...] y luego manifestaron una piedra larga con betas blancas a manera de jaspe que era ydolo conopa para el augmento de papas" (Duviols 2003: 485, 701).

Parece razonable pensar que estas wankas protegían y auspiciaban buenas cosechas, entre otras funciones, en cuanto contenían el espíritu de los ancestros, arraigándolo en una roca excepcional y perdurable. Ciertamente, hasta ahora, en el noroeste argentino se disponen pequeños monolitos en donde se entierran las ofrendas dedicadas a la Madre Tierra, reconocidos como "piedras Pachamama" (Mariscotti 1978). En suma, la aplicación de litos con formatos particulares o en ciertos ordenamientos, asociados a cultivos, tiene sentido, porque en "las rocas se reconocen las mayores hierofanías con valores cúlticos en cuanto revelan poder y dureza de lo eterno" (Eliade 1998: 210).

\section{$*$ Conclusiones}

Un aspecto en común de los ritos expuestos es que ocurren precisamente en ambientes vallesteros, esencialmente maiceros, y aluden a íconos zoomorfos representados tanto en el arte rupestre como en distintas artesanías asociadas a roles simbólicos prehispánicos. Se suman aquellos componentes parafernálicos asociados, que inciden en prácticas ceremoniales distintivas, tales como la aplicación de piezas de oro, plumas de parina, quemas aromáticas, piedras semipreciosas, tierras de colores, vasijas, quiebras de cántaros, ofrendas de alimentos, textiles de prestigio y lugares o wakas consagradas a las rogativas y sacrificios de segura filiación prehispánica.

En territorios desérticos afectados por recurrentes variaciones de temperaturas, fluctuaciones del agua de regadío, disponibilidad de abonos, efectos aluvionales y reparto asimétrico de mano de obra exigían ritos auspiciatorios en torno al multiplico agrario en términos reiterados y decisivos para el colectivo social. En cuanto estos cultos en torno a la fertilidad agraria se enmarcaban en los inicios del ciclo productivo, durante eventos rituales acentuados, surgía un ambiente propicio para la emergencia de diversas prácticas ceremoniales:

“...así mesmo dos beses a el año la una a las primeras aguas antes de haser sus chacaras la otra por tiempo de Corpus quando empiesa a madurar el mais juntan ofrendas en todos sus ayllos y pueblo y se las entregan a los dichos viejos hechiseros y ellos ban a los malquis guacas ydolos y se las ofresen para que les den muchas comidas aumentos en los yndios y que no aya enfermedades y tengan buenos años y aviendoles hecho dichos sacrificios confesaban todos los yndios e yndias a el uso xentilicio en una cancha questa apartada de este dicho pueblo" (Duviols 2003: 444).

Existiría una correlación entre la capacidad de los ayllus más alejados de los templos, para conservar y realizar clandestinamente sus ritos prehispánicos en tiempos en que esta "religión nativa" se deslizaba subrepticiamente de un modo paralelo, con o sin asimilación de ciertos marcadores cristianos, que desde el siglo XVIII se retroalimentaron hasta fusionarse con las prácticas evangelizadoras actuales (Cereceda 1978: 9).

Durante la catequesis impuesta en los asentamientos andinos de alta densidad y complejidad, algunos ritos locales fueron tempranamente incorporados para facilitar el acceso a la nueva doctrina y luego, una vez consolidada, pasaron a ser extirpados (Estenssoro 2001). No obstante, en estos territorios periféricos alejados de los centros de poder, los cultos prehispánicos no tuvieron esa segunda oportunidad. Fueron derechamente extirpados y, en consecuencia, pasaron a conformar una práctica clandestina, perviviendo algunos remanentes hasta hoy. Las rogativas aymaras y atacameñas aún exhiben su asimilación a la evangelización en conjunto con ceremonias prehispánicas como los llamados a las lluvias y el incremento del regadío.

En estas prácticas prohibidas, la lengua kunza, mientras estuvo vigente, acompañó a los rituales antiguos. Era el medio más eficaz para sostener la resistencia y su religiosidad preexistente y por ello fue sometido también a su exterminio (Hidalgo 1984). Ciertamente, una vez ejecutadas las quemas de los ídolos descritos en un marco de franca tensión y castigo, se procedió a cumplir con los Santos Sacramentos de las misas solemnes en los pueblos donde se habían sorprendido los actos idolátricos. Entre el pánico y el fervor, el documento comentado sostiene 
que los atacameños cantaron: "en su lengua himnos y alabanssas...". El kunza estaba vivo y con ello la posibilidad de conservar y reivindicar sus propios ritos.

El pasado ideológico prehispánico, aunque fue directamente intervenido por la represión cultural de los siglos XVI y XVII, persistía en intentar el rescate de su imaginario idealizado, por cuanto las comunidades locales entendían que su subordinación era irreversible y que sus dioses ya no volverían. Sin embargo, a lo menos en sus celebraciones andinas estas prácticas se trasformaban en catarsis colectivas y liberadoras, lo cual no era un logro menor en medio del dominio avasallador de la evangelización (Cummins 1993).

La identificación de imágenes determinadas, que se construyeron en la cultura visual atacameña ha valorado su representación simbólica en relación a espacios sacralizados y productivos a la vez. Resulta coherente que en una doctrina sustentada en varios "ídolos" que, en el fondo, se constituían en el "doble" mueble de aquello inmueble que se adora en el territorio étnico, fueran éstos los que recibieran el mayor castigo por su carácter de mediadores entre las rogativas y el poder de los númenes andinos. Si los ancestros humanos eran representados por las wankas litomorfas (Duviols 1979), ipor qué no pudo irradiarse en los Andes sureños una particular "faunilatría" que debía aparentar y reproducir los poderes sobrenaturales de la tierra fértil?
Podría admitirse que en las sociedades dependientes de recursos agrarios las prácticas ceremoniales se deberían orientar obviamente a la obtención de óptimas cosechas. La cuestión radicaba en que desde las fuentes arqueológicas per se esta posibilidad interpretativa ha sido poco explícita. En este sentido, el aporte etnohistórico y etnográfico abre ventanas insospechadas para reivindicar ciertos cultos atacameños prehispánicos que se infiltraron clandestinos hasta ocultarse temporalmente en los propios archivos coloniales.

Agradecimientos Los autores agradecen al historiador Carlos Ruiz por su cuidadosa transcripción del documento comentado. El primer autor reconoce la gentileza del personal del Archivo General de Indias de Sevilla y, paralelamente, agradece a Drahomíra Srýtrová por su ayuda en el manejo de esas fuentes documentales. Esta investigación se realizó durante el período de año sabático del primer autor, correspondiente a 2007. Por su parte, Victoria Castro agradece al Dr. José Luis Venero, ornitólogo, quien identificó el picaflor del petrograbado presentado en este trabajo. También agradece al Dr. Lautaro Núñez por su generosa invitación a participar como coautora de este escrito, y a Isabel Cartajena por su apreciada gentileza. Ambos autores agradecen las excelentes sugerencias al texto de Cecilia Sanhueza, editora asociada de Estudios Atacameños.

\section{* ANEXO}

El presente documento textual corresponde al año 1677 y proviene del Archivo General de Indias "Informaciones de oficio y parte: Domingo Suero Leiton de Rivera, presbítero, cura y vicario del pueblo de San Francisco de Chiochio, provincia de Atacama la Baja. Testimonio de 1677 , certificado en 1678 ", 12 fs. (AGI, Lima, 263 núm. 9). ${ }^{8}$

"Visitador General de este arçobispado en este asiento de San Antonio de los Lipes en dies y ocho días del mes de Diziembre de mill y seiscientos y setenta y dos años siendo testigos el lizensiado Bernardo Balviny

\footnotetext{
8 Un segundo documento muy similar, correspondiente al año 1674, está clasificado en "Informaciones de oficio y parte: Domingo Suero Leiton de Ribera, bachiller, cura y vicario del pueblo de Cubija y sus anejos. Solo testimonios y certificaciones" ( AGI Charcas, 98, núm. 4).
}

Diego Gomes de Lara presentes = Ante mi Martin Perez de Estrada Notario de visita.

\section{Notificacion}

En el asiento de San Antonio del Nuebo Mundo de los Lipes en dies y ocho días del mes de Diziembre de mill y seisçientos y setenta y dos años yo el presente notario de Visita notifique la sentencia de esta otra parte como en ella se contiene al Bachiller Domingo Suero Leiton de Rivera en su perssona que la oyo de que doy fee = Martin Peres de Estrada Notario de Visita = Concuerda este traslado con su original de a donde se sacó que queda en la caussa de visita secreta. Va cierto y verdadero corregido y consertado y de pedimento del Bachiller Domingo Suero Leiton de Rivera $y$ de mandamiento del señor Visitador General di el pressente testimonio en el asiento de San Antonio del Nuebo Mundo de los Lipes en dies y nuebe días del mes de Diziembre de mill y seisçientos y setenta y dos años = En testimonio de verdad Martin Perez de Estrada Notario de visita. 
Testimonio de aver quitado ydolos

Yo don Joseph de la Torre y Salassar escrivano del Rey nuestro Señor certifico doy fee y testimonio de verdad a los que el presente vieren como aviendo ydo a los pueblos de Lassana, Caspana y Aiquina Jurisdision de la provincia de Atacama la Vaja desde este pueblo de San Françisco de Chio Chio de dicha provincia en compañia del Bachiller Domingo Suero Leiton de Rivera Cura y Vicario de dicho pueblo puerto de Cubija y sus anejos le vi sacar tres ydolos el uno en el dicho pueblo de Lassana en forma de un platillo quadrado de madera de algarobo con dos figuras de ximios en cuio hueco echavan comidas las primeras que los yndios de dicho pueblo cogian en sus sementeras a quien ofresian adorassion, y el otro en el pueblo de Caspana a manera de lagarto de la mesma madera con la voca avierta al qual le ofresian piedras de varios colores de pedernales $y$ polvos de colores y davanle adorassion en un alto serro que mira al de Potossi en el dicho pueblo de la Yquina saco el tersero ydolo de en medio de un caudaloso rio que estava colocado en una peña que estava en la mitad de ely la bañavan las aguas por entrambos lados a este ydolo segun dixeron los casiques le rendian adorassion y culto llevando el prinsipal Governador en las manos una olla nueba y otras veses cargandola en las espaldas y llena de mais yba la yndia mas ansiana con un palito sutily delgado tocandola y en llegando que llegavan con esta seremonia al rio quebravan la olla en la dicha peña y levantando el grito a voses desian caiatunar que en su lengua materna dissen lo que en nuestro ydioma hispanico buena cosecha para conservasion de la extirpasion de dichos ydolos yo el presente escrivano en compañia del dicho Cura y Vicario fui a los paraxes referidos por caminos muy agrios y passe por una cordillera tan aspera con peligro conosido de la vida por los huracanes y nieves que son tan continuas que de dia y de noche caen, nebando sobre sus empinadas cumbres continuamente caminando a veses por los passos estrechosy peligrossos a pie muchas leguas comiendo el dicho Cura raises de junquillo yerba con que se sustentan los miserables yndios de dicha provinçia a quienes reduxo y hizo que avominassen sus superstisiones predicandoles la fe de Dios instruiendoles en los prinsipales misterios de nuestra santa $f e$, en lo qual estan firmes conosiendo sus herrores y veneran con grande efecto a Jesuchristo y a su madre santisima acudiendo todos con grande devosion al templo a cantar en su lengua himnos y alabanssas a Rey $y$ reina tal esclaresida esmerandose en el adorno y culto de las yglecias de dichos pueblos en los quales a fabricado los que estavan caidos que son tres a expenssas de las cortas obensiones que persive y para que conste lo referido de pedimiento del susso dicho doy el pressente en dicho pueblo de San Françisco de Chio Chio en veinte y siete dias del mes de septiembre de mill seiscientos y setenta y quatro años siendo testigos el maestro de Campo Don Bartolome Velarde corregidor que a sido de dicha provinsia y el maestro de Campo Don Antonio Gutierrez Caro su susessor corregidor de ella y el capitan Pedro de Chaves Morejon alguaçil mayor nombrado de dicha provinçia presentes. $=$ Paso ante mi y en fe de ello lo signo y firmo en testimonio de verdad derechos quatro reales foxa Don Joseph de la Torre escrivano de su Magestad.

Fe de vida

Yo Don Joseph de la Torre y Salassar escrivano del Rey nuestro Señor certifico doy fe y testimonio de verdad a los que el presente vieren como oy dia de la dicha vi y veo al Bachiller Domingo Suero Leiton de Rivera Cura y Vicario de la provincia de Atacama la Vaja puerto de Cubixa y demas anejos sano y bueno y con espiritu de vida y para que asi conste de pedimiento del dicho doy el presente en dicha provinsia y pueblo de San Françisco de Chio Chio en siete dias del mes de octubre de mill y seisçientos y setenta y quatro siendo testigos el capitan Pedro Chaves Morejon y Lorenso de Almendaris pressentes a quienes doy fe conozco. $=$ Don Joseph de la Torre escrivano de su Magestad.-

\section{Fe de bautismo}

Yo Don Joseph de la Torre y Salassar escrivano del Rey nuestro señor:= Certifico doy fe y testimonio de verdad a los que el presente vieren como en un libro aforrado en pergamino donde se escriben los Bautisados en esta Iglecia mayor de la Villa de Potossi que comiensa del año de mill y seisçientos y treinta y seis esta una partida del thenor siguiente.-

En Potossi a veinte y nueve de junio de mill y seisçientos y treinta y seis años bautisse, puse olio y chrisma a Domingo Suero Leiton de Rivera hijo legitimo de Juan Suero Leiton y de Doña Françisca de Rivera y fueron sus padrinos Jorxe Gonsales y Cathalina Sanches y lo firme el Lizensiado Bernardo de Alfaro= segun consta y paresse de dicho libro a foxas onsse buelta, a que en lo necesario me remito en cuio testimonio doy el pressente en esta Villa Ymperial de Potossi en dies y ocho de agosto de milly seisçientos y setenta y quatro años, siendo testigos Miguel de Leyba y Christoval Dias. = Don Joseph de la Torre escrivano de su Magestad.

Concuerda este traslado con los titulos originales y carta que esta en ellos para cuio efecto exsivio ante mi el Bachiller Domingo Suero Leiton de Rivera Cura y Vicario de este pueblo de San Francisco de Chio Chio provinçia de Atacama la Vaja y volvio a llevar a su poder a que me remito y para que de ello conste de su pedimiento doy el pressente en dho pueblo en treinta de marzo de mill y seisçientos y setenta y siete años, siendo testigos Alonso Dias Gata y Francisco Gutierrez de Herrera pressentes.- Enmendado $=$ sentaz $=$ vale -

En fe de ello lo signo y firmo.

En testimonio de verdad

Dêrechos Quatro Reales foja.

Estevan de Marquina Escribano de su Magestad [Rubricado]

Los escrivanos del Rey nuestro Señor que aqui signamos y firmamos çertificamos y damos fe que Estevan de Marquina de quien el testimonio de susso ba signado y firmado es escrivano de su Magestad como se nombra fiely legaly como a tal a las escrituras certificasiones testimonios y demas autos y diligensias que ante el an pasado y pasan se les a dado y da entera fe y credito en juiçio y fuera de el y para que de ello conste damos la pressente en la Villa de Potossi en nueve de agosto de mill y seiscientos y setenta y ocho años.

Joan de Torres Escribano Publico y cavildo [rubricado] Miguel Martinez de Muga. Escribano Publico [rubricado] Francisco Ximenez. Escribano Publico [rubricado] 


\section{* Referencias citadas}

\section{Fuentes inéditas}

Archivo General de Indias (AGI), Lima, 263, núm. 9, 1677. Informaciones de oficio y parte: Domingo Suero Leiton de Rivera, presbítero, cura y vicario del pueblo de San Francisco de Chiochio, provincia de Atacama la Baja. Testimonio de 1677, certificado en $1678,12 \mathrm{fs}$.

\section{Bibliografía}

ACOSTA, J. de, 1954 [1590]. Historia natural y moral de las Indias. Biblioteca de Autores Españoles 73, Madrid.

ANÓNIMO, 1970 [1603]. Arte de la lengua general del Perúllamada quichua. Clemente Hidalgo Impresores, Sevilla.

ARNOLD, D., D. JIMÉNEZ y J. D. YAPITA, 1992. Hacia un orden andino de las cosas. HISBOL/ILCA, La Paz.

ARRIAGA, J. de, 1958 [1621]. La extirpación de la idolatría en el Perú. Biblioteca de Autores Españoles 209. Atlas, Madrid.

BARBA, A. 1967 [1639]. El arte de los metales. Editorial Potosí, Potosí.

BARTHEL, T. 1986 [1957]. El agua y el festival de la primavera entre los atacameños. Allpanchis 18 (28): 147-184.

BERENGUER J. 1985. El método histórico directo en Arqueología. Boletín de Prehistoria de Chile 9: 63-72.

BERENGUER, J.y J. L. MARTÍNEZ, 1986. El río Loa, el arte rupestre de Taira y el mito de Yakana. Boletín del Museo Chileno de Arte Precolombino 1: 79-99.

BIBAR, J. de, 1979 [1558]. Crónica y relación copiosa y verdadera de los reynos de Chile. Edición de Leopoldo Sáez Godoy. Biblioteca Ibero Americana, Berlín.

BOUYSSE-CASSAGNE, TH. 1997-1998. El sol de adentro: Wakas y santos en las minas de Charcas y en el lago Titicaca (siglos XV a XVII). Boletín de Arqueología PUCP 8: 59-97.

2004. Minas del Sol, del Inka y de la gente. Potosí en el contexto de la minería. En Mina y metalurgia en los Andes del sur desde la etapa prehispánica hasta el siglo XVII, P. Cruz y J. J. Vacher (Eds.), pp. 303-348. IFEA, Sucre.

BRIONES, L. 2008. Geoglifos del Norte de Chile, Región de Arica y Parinacota. Salesianos Impresores, Santiago.
BRIONES, L. y G. ESPINOZA, 1991. Investigación y rescate de un sitio con arte rupestre: Cerro Colorado, I Región, norte de Chile. Revista SIARB 5: 80-86.

CASTRO, V. 1986. An approach to the Andean Etnozoology: Toconce. En Cultural attitudes to animals including Birds, Fish and Invertebrates, vol. 2, pp. 1-17. Allen \& Unwin, Londres.

1993. Un proceso de extirpación de idolatrías en Atacama, siglo XVII. En Catolicismo y extirpación de idolatrías, siglos XVI-XVIII, G. Ramos y E. Urbano (Comps.), pp. 347-366. Centro de Estudios Regionales Andinos Bartolomé de las Casas, Cusco.

1997. Huacca Muchay. Evangelización y religión andina en Charcas, Atacama La Baja. Tesis de magíster en Historia, Mención Etnohistoria, Universidad de Chile, Santiago.

2004. El picaflor de la gente (Sotar Condi). Ornitología Neotropical 15 (Supl.): 409-417.

CASTRO, V. y V. VARELA, 1991. Así sabían contar. Oralidad 4: 4-16. UNESCO, La Habana.

(Eds.), 1994. Ceremonias de tierra y agua. Ritos milenarios andinos. FONDART, Fundación Andes. Imprenta Kuppenheim, Santiago.

CAYON, E. 1971. El hombre y los animales en la cultura quechua. Allpanchis 3: 135-162.

CERECEDA, V. 1978. Mundo quechua. Editorial América Profunda, Cochabamba.

COBO, B. 1956 [1653]. Historia del nuevo mundo. Biblioteca de Autores Españoles, vol. 91-92, Madrid.

CONDORI, D. 1991. El sistema aymara de previsión del tiempo agrícola. El caso Maquercota - Pilcuyo (Puno). CIDSA, Puno.

CRUZ, P. J., P. ABSI y S. FIDEL, 2005. ¿Y entonces dónde estaban los indios? La ocupación de Potosí antes de la llegada de los españoles. Anuario de Estudios Bolivianos, Archivísticos y Bibliográficos 11: 75-101. Ediciones Archivo y Biblioteca Nacionales, Sucre.

CRUZ P. J. y P. ABSI, 2008. Cerros ardientes y huayras calladas. Potosí antes y durante el contacto. En Mina y metalurgia en los Andes del sur desde la etapa prehispánica hasta el siglo XVII, P. Cruz y J. J. Vacher (Eds.), pp. 91-120. IFEA, Sucre.

CUMMINS, T. 1993. La representación en el siglo XVI. La imagen colonial del Inca. En Mito y simbolismo en los Andes. La figuray la palabra, 
H. Urbano (Comp.), pp. 87-136. Centro de Estudios Regionales Andinos Bartolomé de las Casas, Cusco.

DUVIOLS, P. 1967. Un inédit de Cristóbal de Albornoz: La instrucción para descubrir todas las guacas del Pirú y sus camayos y haziendas. Journal de la Societé des Americanistes 56 (1): 7-39, París.

1979. Un symbolisme de l'occupation, de l'aménagement et de l'exploitation de l'espace. Le monolithe "huanca" et sa fonction dans les Andes préhispaniques. L'Homme, Revue Française d'Anthropologie 19 (2): 7-31.

2003. Procesos y visitas de idolatrías. Cajatambo, siglo XVII con documentos anexos. IFEA/PUCP, Lima.

ELIADE, M. 1998. Lo sagrado y lo profano. Paidós Ibérica, Barcelona.

ESTENSSORO, J. C. 2001. El simio de Dios: Los indígenas y la iglesia frente a la evangelización del Perú, siglos XVI - XVII. Boletín del Instituto Francés de Estudios Andinos 30 (3): 455-474.

FLORES, J., E. KUON y R. SAMANEZ, 1998. Qeros. Arte Inka en vasos ceremoniales. Banco de Crédito del Perú, Lima.

GALLARDO F. y V. CASTRO, 1992. El poder de las imágenes: Etnografía en el Río Salado (Desierto de Atacama). Creces 13 (4): 16-23.

GALLARDO, F., C. SINCLAIRE y C. SILVA, 1999. Arte rupestre, emplazamiento y paisaje en la cordillera del desierto de Atacama. En Arte rupestre en los Andes de Capricornio, J. Berenguer y F. Gallardo (Eds.), pp. 57-96. Museo Chileno de Arte Precolombino, Santiago.

GARCILASO DE LA VEGA, INCA, 1960 [1609]. Comentarios reales de los incas. Biblioteca de Autores Españoles, vol. 133, Madrid.

GIRAULT, L. 1987 Kallawaya. Curanderos Itinerantes de los Andes. La Paz.

GISBERT, T. 1980. Iconografía y mitos indígenas en el arte. La Paz. 2010. El Cerro de Potosí y el dios Pachacamac. Chungara 42 (1): $169-180$.

GISBERT, T. y J. MESA, 1985. Arquitectura andina 1530-1830. Historia y análisis. Don Bosco, La Paz.

GUAMAN POMA DE AYALA, F. 1936 [1614]. Nueva crónica y buen gobierno. Institut d'Ethnologie, Université de Paris.

HALBERTAL, M. y A. MARGALIT, 2003. Idolatría. Guerras por imágenes, las raíces de un conflicto milenario. Editorial Gedisa, Barcelona.
HIDALGO, J. 1984. Descomposición cultural de Atacama en el siglo XVIII: lengua, escuela, fugas y complementariedad ecológica. En Actas del Simposio Culturas Atacameñas, pp. 221-249. $44^{\circ}$ Congreso Internacional de Americanistas, Universidad del Norte, Antofagasta.

KUSCH, R. 1970. El pensamiento indígena americano. Editorial J. M. Cajica Jr., Puebla, México.

LATCHAM, R. 1938. Arqueología de la región atacameña. Prensas de la Universidad de Chile, Santiago.

LEVI-STRAUSS, C. 1986. Mitológicas. Lo crudo y lo cocido, I. Fondo de Cultura Económica, México. 1992. El origen de las maneras de mesa. J. Almela (Trad.). Siglo XXI Editores, México.

LLAGOSTERA, A., M. TORRES y M. A. COSTA, 1988. El complejo psicotrópico en Solcor-3 (San Pedro de Atacama). Estudios Atacameños 9: 61-98.

MALDAVSKY, A. 1999. Cartas anuas y misiones de la Compañía de Jesús en el Perú: siglos XVI - XVIII. En Cosmovisión religiosa andina en los documentos inéditos del Archivo Romano de la Compañía de Jesús 1581-1752, M. Polia Meconi (Ed.), pp. 17-76. Pontificia Universidad Católica del Perú, Lima.

MARISCOTTI, A. M. 1978. Pachamama Santa Tierra. Contribución al estudio de la religión autóctona en los Andes centro-meridionales. Indiana 8. Gebr. Mann Verlag, Berlín.

MARTÍNEZ, G. 1976. El sistema de los Uywiris en Isluga. En Homenaje al R. P. Gustavo Le Paige, H. Niemeyer (Ed.), pp. 255-327. Universidad del Norte, Antofagasta.

MARTÍNEZ, J. L. 1995. Autoridades en los Andes, los atributos del señor. Pontificia Universidad Católica del Perú, Lima.

MARTÍNEZ SOLER, B. J. 1958-1959. Conchyliologia Ethnologica. El uso ornamental y ceremonial de algunas especies de moluscos en territorio argentino en relación con los desplazamientos étnicos y el comercio indígena prehispánico. En Runa. Archivo para las Ciencias del Hombre IX: 267-322.

MONTELL, G. 1926. An archaeological Collection from the Rio Loa valley, Atacama. Etnografiske Museums Skrifter, Oslo.

MOSELEY, M. E. 1993. The incas and their ancestors: the archaeology of Peru. Thames and Hudson, London.

MOSTNY, G. 1969. Ideas mágico-religiosas de los Atacamas. Boletín del Museo Nacional de Historia Natural XXX: 133-140, Santiago. 
MOstNY, G., F. JELDES y R. GONZÁLEZ, 1954. Peine, un pueblo atacameño. Editorial Universitaria, Santiago.

MUÑOZ, I. 1983. Hallazgo de un alouatta seniculus en el valle de Azapa. Estudio preliminar de la iconografía de simios en Arica. Chungara 10:39-46.

MURRA, J. 1975. El tráfico de Mullu en la costa del Pacífico. En Formaciones económicas y políticas del Mundo Andino. J. Murra (Ed.), pp. 255-267. Instituto de Estudios Peruanos, Lima.

NÚÑEZ, L. 1961. La escultura antropomorfa prehispánica en el norte de Chile. Boletín de la Universidad de Chile 26: 56-60.

1963. Los keros del Norte de Chile. Revista de Antropología 1: 72-88.

1984. Tráfico de complementariedad de recursos entre las tierras altas y el Pacífico en el área centro sur andina. Tesis de doctorado, Universidad de Tokio, Tokio.

NÚÑEZ, L. y L. BRIONES, 1967-1968. Petroglifos del sitio Tarapacá-47 (Provincia de Tarapacá). Estudios Arqueológicos 3-4: 43-84.

NÚÑEZ, L., I. CARTAJENA, J. P. LOO, S. RAMOS, T. CRUZ y H. RAMÍREZ, 1997. Registro e investigaciones del arte rupestre en la cuenca de Atacama. (Informe preliminar). Estudios Atacameños 14:307-326.

NÚÑEZ L., I. CARTAJENA, C. CARRASCO y P. DE SOUZA, 2005. El templete de Tulán y sus relaciones formativas panandinas (norte de Chile). Bulletin de l'Institut Français d' Ëtudes Andines 34 (3): 299-320.

NÚÑEZ, L., P. DE SOUZA, I. CARTAJENA y C. CARRASCO, 2007. Quebrada Tulán: Evidencias de interacción circumpuneña durante el formativo temprano en el sureste de la cuenca de Atacama. En Producción y circulación prehispánicas de bienes en el sur andino, A. Nielsen, M. C. Rivolta, V. Seldes, M. Vásquez y P. H. Mercolli (Comps.), pp. 287-303. Editorial Brujas, Córdoba.

OLIVA, J. A. 1895 [1598]., Historia del reino y provincias del Perú, de sus Incas reyes, descubrimiento y conquista por los españoles de la corona de Castilla con otras singularidades concernientes a la historia. Pasos Varela, Lima.

PLATT, T. 1976, Espejos y Maíz. Temas de la Estructura Simbólica andina. Cuaderno 10, CIPCA, La Paz.
PONTI, M. 2008. El simbolismo del colibrí en la Historia de América: encuentro y desencuentro de dos mundos. Tesis de licenciatura, mención Historia. Facultad de Humanidades, Universidad Adolfo Ibáñez, Santiago.

REICHE, M. 1982. Nazca Perú. Secreto de la Pampa. Heinrich Fink GMBH, Stuttgart.

RICARDO, A. 1951 [1586]. Vocabulario y praxis en la lengua general del Perú, Lima.

ROSTWOROWSKI, M. 1970. Mercaderes del valle de Chincha en la época prehispánica: un documento y unos comentarios. Revista Española de Antropología Americana 5: 135-178.

RYDEN, S. 1944. Contribution to the archaeology of the rio Loa region. Elanders Boktrickery Aktiebolag, Göteborg.

TORRES, C. 1984. Tabletas para alucinógenos de San Pedro de Atacama: Estilo e Iconografía. Tesoros de San Pedro de Atacama: 23-36. Museo Chileno de Arte Precolombino, Santiago.

1987. The Iconography of south American Snuff Trays and related paraphernalia. Etnologiska Studier 37:1-133 Göterborg.

TORRES, D. de, 1966 [1616]. Arte de la lengua aymara. Gramática y vocabulario compuesto por el Padre Diego de Torres Rubio en 1616. Actualización y uso del nuevo alfabeto por M. Franco en 1966. Lyrsa, Lima.

TSCHOPIK, H. 1946. The aymara. En Handbook of South American Indians (Vol. 2), The Andean civilizations. J. H. Steward (Ed.), pp. 501-573. Government Printing Office, Washington, D. C.

URIOSTE, G. 1983. Hijos de Pariya Qaqa: La tradicón Oral en Waru Chiri. Maxwell School of Citizenship and Public Affaire, Siracusa, New York.

VAIISSE, E., F. HOYOS y A. ECHEVERRÍA, 1896. Glosario de la lengua atacameña. Imprenta Cervantes, Santiago.

VAN KESSEL, J. 1980. Holocausto al progreso. Los aymaras de Tarapacá. CEDLA, Amsterdam.

VÁSQUEZ DE ESPINOZA, A. 1948 [1628]. Compendio y descripción de las Indias Occidentales. The Smithsonian Institution, Washington. 